\title{
Resource availability and diet in Harpy Eagle breeding territories on the Xingu River, Brazilian Amazon
}

\author{
Aguiar-Silva, FH. ${ }^{a, b^{*}}$, Junqueira, TG. ${ }^{c}$, Sanaiotti, TM. ${ }^{b, d}$, Guimarães, VY. ${ }^{c}$, \\ Mathias, $P V C .^{c}$ and Mendonça, $C V^{c}$ \\ aPrograma de Pós-Graduação em Ecologia, Instituto Nacional de Pesquisas da Amazônia, \\ Av. André Araújo, 2936, Aleixo, CEP 69067-375, Manaus, AM, Brazil \\ 'Programa de Conservação do Gavião-real - PCGR, Av. André Araújo, 2936, Aleixo, CEP 69067-375, Manaus, AM, Brazil \\ 'Biota Projetos e Consultoria Ambiental Ltda., Rua 86 C, 64, Setor Sul, CEP 74083-360, Goiânia, GO, Brazil \\ 'Instituto Nacional de Pesquisas da Amazônia, Av. André Araújo, 2936, Aleixo, CEP 69067-375, Manaus, AM, Brazil \\ *e-mail: aguiarsilva.fh@gmail.com
}

Received: June 2, 2014 - Accepted: December 1, 2014 - Distributed: August 31, 2015

(With 3 figures)

\begin{abstract}
In the Tapajos-Xingu interfluve, one of the largest birds of prey, the Harpy Eagle, is under intense anthropogenic pressure due to historical and recent reductions in forest cover. We studied prey availability and use by Harpy Eagle on six breeding territories on the low- and mid-Xingu River, between 2013 and 2015. We evaluated food resource availability using the environmental-surveys database from two methods: terrestrial surveys (RAPELD method) and fauna rescue/flushing before vegetation suppression for the Belo Monte Hydroelectric Complex construction. Harpy Eagle diet was identified by prey remains sampled around six nest trees. Eighteen species of mammals, birds and reptiles comprised the prey items. Most prey species were sloths, primates and porcupines, which have arboreal habits and are found in forested areas, but two species, hoatzin and iguana, are usually associated with riverine habitats. The proportion of prey from each species predated on the nest best studied was different from estimated availability $\left(\chi^{2}=54.23 ; \mathrm{df}=16 ; \mathrm{p}<0.001\right)$, however there was a positive correlation $\left(\mathrm{r}_{\mathrm{s}}=0.7 ; \mathrm{p}<0.01\right)$ between prey species consumed and abundance available, where the predation was more on species more abundant. Continuous monitoring of the Harpy Eagle diet at these nests could evidence changes in the assemblage of prey species available for Harpy Eagles, due to changes in the seasonal flood pulse of the Xingu River to be caused by the operation of the hydroelectric dam, and changes in habitat features by forest reduction around breeding territories. We believe that it is important to consider the protection of remnants of forested areas in the landscape matrix surrounding the breeding territories to maintain the food resource availability and allow all pairs to successfully reproduce.
\end{abstract}

Keywords: Behavioral ecology, Harpia harpyja, predator, mammals, Xingu River.

\section{Disponibilidade e consumo de presas por harpia no entorno de territórios de nidificação no rio Xingu, Amazônia Oriental Brasileira}

\section{Resumo}

O interflúvio Tapajós-Xingu, um dos centros de endemismo da Amazônia, onde habita uma das mais poderosas aves de rapina, a harpia, é também alvo de intensa pressão antrópica com reduções históricas da cobertura florestal. Analisamos a disponibilidade de vertebrados e o consumo de presas por harpia em seis territórios de reprodução no Rio Xingu, entre 2013 e 2015. A disponibilidade de recursos alimentares foi baseada nos dados de amostragens por dois métodos: levantamentos terrestres pelo método RAPELD e resgate/afugentamento da fauna antes da supressão da vegetação para construção de infra-estrutura para o Complexo Hidrelétrico Belo Monte. As espécies de presas consumidas pela harpia foram identificadas a partir de vestígios coletados em seis ninhos. Dezoito espécies de mamíferos, aves e répteis compuseram a dieta no baixo e médio Rio Xingu, com maior proporção de preguiças, macacos e porcos-espinhos, incluindo duas espécies (Opisthocomus hoazin e Iguana iguana) associadas aos hábitats criados por rios. A proporção de indivíduos das espécies predadas no ninho com maior número de coletas foi diferente da disponibilidade $\left(\chi^{2}=54,23 ; \mathrm{gl}=16 ; \mathrm{p}<0,001\right)$, no entanto, existe correlação positiva $\left(\mathrm{r}_{\mathrm{s}}=0,7 ; \mathrm{p}<0,01\right)$ entre o consumo de presas e a abundância disponível, com a predação maior sobre espécies mais abundantes. A riqueza de presas indica que as florestas remanescentes na região foram fonte eficiente de recursos alimentares para a reprodução e manutenção da harpia. O monitoramento da dieta da harpia nos ninhos pode apresentar alterações relacionadas às mudanças no pulso sazonal de inundação do Xingu, provocadas pelo futuro funcionamento da usina hidrelétrica e à redução da floresta no entorno dos ninhos localizados no Reservatório Xingu e Intermediário. É importante considerar a proteção dos remanescentes florestais no entorno dos territórios de nidificação para garantir a disponibilidade de presas e a reprodução efetiva dos casais de harpia na região.

Palavras-chave: Ecologia comportamental, Harpia harpyja, predador, mamíferos, Rio Xingu. 


\section{Introduction}

The Tapajos-Xingu interfluve is under intense anthropogenic pressure due to historical and recent reductions in forest cover, mainly due to governmental development programs in the region, such as the construction of roads, agricultural settlements, large cattle ranches and dams (Soares Filho et al., 2005; Davidson et al., 2012). The Xingu basin harbors great species diversity (Pacheco and Olmos, 2005), and many species, such as the larger primates and birds of prey, are vulnerable or threatened due to advancing deforestation (Ravetta and Ferrari, 2009; Trinca et al., 2008). Conservation plans are being developed for several of these species, and specifically, the Conservation Plan of Lower and Mid-Xingu River (PAN Xingu) includes two bird of prey species, Harpy Eagle Harpia harpyja (Linnaeus) and Crested Eagle Morphnus guianensis (Linnaeus) (Brasil, 2012, 2014a).

The Harpy Eagle (Aves: Accipitridae), is one of the largest birds of prey in the world (Ferguson-Lees and Christie, 2001), but on a global scale it is classified as Near Threatened (NT) due to the possibility of a population decline (IUCN, 2015), and Vulnerable (VU) (A4 cd) by the Brazilian Environmental Agency's Red List of Threatened Species (Brasil, 2014b), due to forest fragmentation and removal of reproductive individuals by hunting and persecution (Trinca et al., 2008; DeLuca, 2012).

To conserve the Harpy Eagle populations, it is necessary to maintain the quality of resources available in reproductive territories (Soares et al., 2008). Territory quality can be measured from the biotic and abiotic resources available and used by the species. Harpy Eagle pairs reuse the same nest tree (Rettig, 1978), suggesting that the breeding territory can be studied to evaluate habitat quality, foraging strategies and reproductive success (Johnson, 2007).

On 15 April 2008, the first active Harpy Eagle nest of the Xingu River was located during the avifauna survey of the area under the influence of the Belo Monte Hydroelectric Complex, as a supplement to the Environmental Impact Assessment (EIA/RIMA) (Henriques et al., 2008). An adult was seen sitting on the nest (S. Dantas, pers. comm.). Below the nest tree, part of a dead howler monkey Alouatta belzebul (Linnaeus) was found, which was evidence that this nest was in an active cycle. In 2013, the Harpy Eagle pair started a new reproductive cycle, during which our monitoring was conducted until July 2015, including collection of feathers for genetic studies (Banhos et al., 2008) and prey remains for diet identification (AguiarSilva et al., 2014a). Since 2014, five other Harpy Eagle nesting trees were mapped near the low- and mid-Xingu River and were also a focus of this study.

Several studies over the wider Neotropics have reported on the composition of Harpy Eagle diet (Fowler and Cope, 1964; Rettig, 1978; Álvarez-Cordero, 1996; Galetti and Carvalho Junior, 2000; Sanaiotti et al., 2001; Piana, 2007; Muñiz-López et al., 2007; Anfuso et al., 2008; AguiarSilva et al., 2014a), and sloths are the main prey species (Aguiar-Silva et al., 2014a). One compared prey species use in relation to availability by standardized method in data collection (Galetti and Carvalho Junior, 2000), but no one has yet included data sets from fauna rescue/flushing counts. Standardized methods have been widely used to estimate fauna composition, but the difficulty was to estimate sloths and other cryptic species with nocturnal habits. Abundance from non-volant fauna rescue, even as a non-standard sampling method, has been found to be effective to sample large-herbivore populations, such as sloths and primates (Mascarenhas and Puorto, 1988). There has been an intensive effort to estimate vertebrate abundance by surveys and non-volant fauna rescue and flushing before vegetation suppression near the Harpy Eagle breeding territories on the low- and mid-Xingu River (Norte Energia, 2014).

The present study aimed to examine whether the proportion of prey species used by the Harpy Eagle pair in a breeding cycle was similar to the proportion of vertebrate species detected by humans (by surveys) in the same area, and to contribute for the Conservation Plan of Xingu River (Brasil, 2012) and to claim to decision makers, effective actions to reduce the impacts of hydroelectric dam construction in Harpy Eagle population on the Xingu River.

\section{Material and Methods}

\subsection{Study area}

This study was conducted on the lower and mid-Xingu River, Para state, Eastern Amazonia, Brazil $\left(2^{\circ} 41^{\prime}-3^{\circ} 57^{\prime} \mathrm{S}, 52^{\circ} 37^{\prime}-51^{\circ} 58^{\prime} \mathrm{W}\right)$ (Figure 1). The area is in the Tapajos-Xingu interfluve and located in the Brasil Novo and Vitoria do Xingu municipalities. The landscape is composed of a mosaic of terra firme forest and flooded (varzea) forests, secondary forests, and deforested areas, mainly used for cattle ranching (Brasil, 2004). In the Xingu Area of Endemism, 37\% of the region has anthropogenic land uses, with conversion of forested areas to pasture, agriculture (Almeida et al., 2014), and hydroelectric infra-structure (Fearnside, 2015). The climate is humid tropical Am according to the Köppen climate classification with a dry season from July to November. Average annual temperature ranged from $17.5^{\circ}-24.5^{\circ} \mathrm{C}$, and relative humidity from $84-86 \%$. Average annual rainfall varied from 2066-2379 $\mathrm{mm}$ in the same period.

Six active Harpy Eagle breeding territories were mapped on this region, two during the terrestrial surveys at RAPELD modules (Magnusson et al., 2005, 2013) named nest Torrão (Nest 1) and nest Module 1 (Nest 2). Another four nesting trees mapped were found during vegetation suppression in 2014 and 2015: nest Xingu Reservoir - CEA (Nest 3), nest Intermediate Reservoir - 55CTCA (Nest 4), nest Intermediate Reservoir - Ticaruca (Nest 5), and nest Intermediate Reservoir - Paquiçamba (Nest 6) (Figure 1).

We distinguished two main habitat types around the six breeding territories, two (Nest 1 and Nest 2) that are outside the hydroelectric dam direct influence, in contrast to the other four (Nests 3, 4, 5 and 6), which are under direct influence of the reservoir and had the vegetation suppressed, in three case, $100 \%$ removed (Nests 4, 5, 6) (Figure 1). 


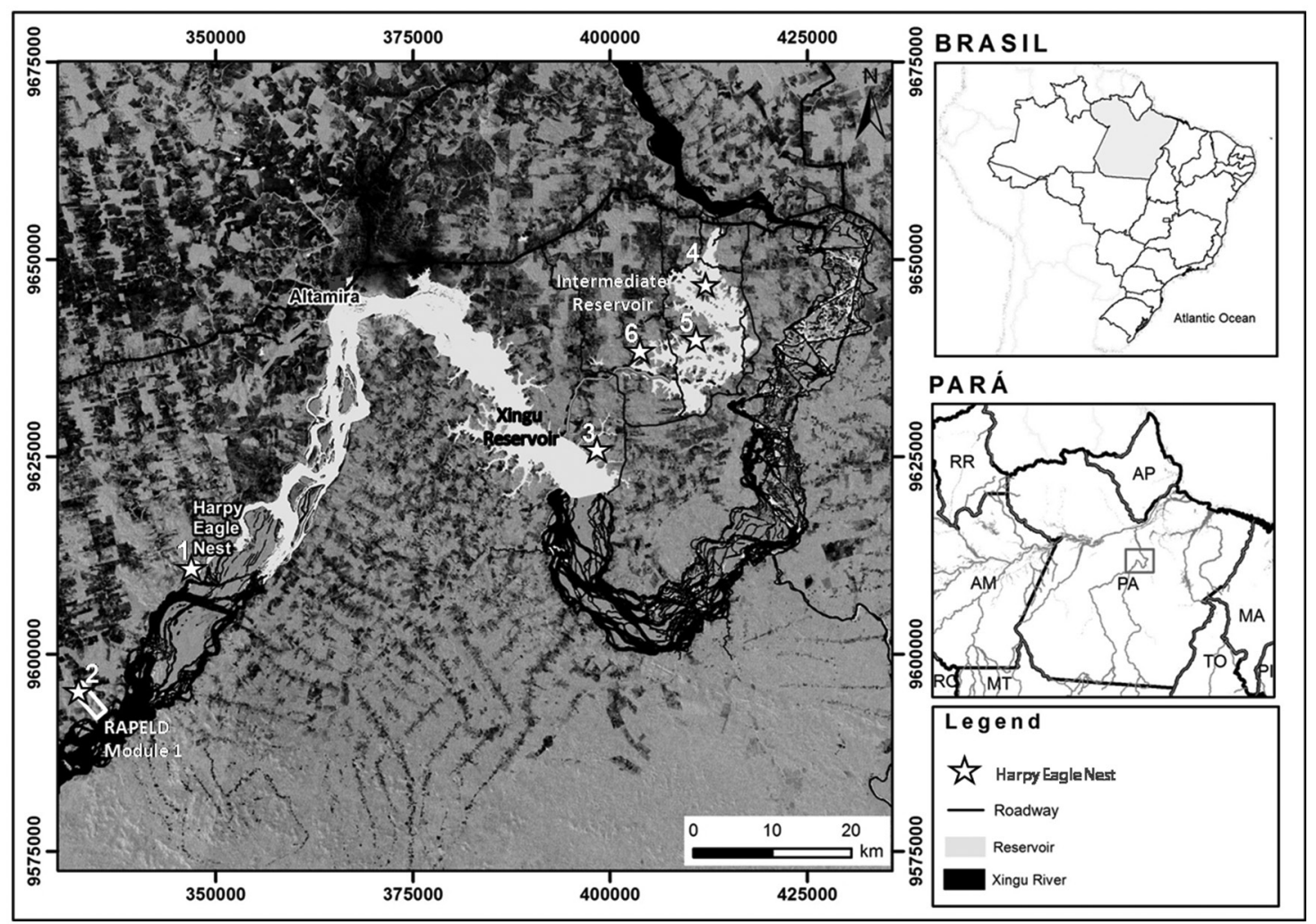

Figure 1. The six Harpy Eagle nests (white star) on the left bank with surrounding matrix (darker gray color represent non-forested areas) and the region of the future reservoirs (Xingu and Intermediate) of the Belo Monte Hydroelectric Complex on the low- and mid-Xingu River, eastern Brazilian Amazonia. RAPELD Module 1 in white rectangle (fauna surveys).

\subsection{Assessment of diet composition}

Prey remains that had fallen from the nest and accumulated on the ground from the beginning of incubation until the juvenile dispersed away from the parents' breeding territory were collected below the nest tree between May 2013 and July 2015 . A stretched $9 \times 10 \mathrm{~m}$ nylon net was installed around the tree trunk (Nest 1) to facilitate collection and increase detection of small pieces of bones, fur, hair, claws and teeth. A climber accessed three nests (Nest 1, $2,4)$ to collect dimensions of the tree and nest, and prey remains accumulated in the nest. Nests 4, 5 and 6 had prey remains collected once. Prey species were identified and quantified from bones of the skull, mandible, femur, pelvis, teeth, hair, and feathers (Aguiar-Silva et al., 2014a) by comparison with Mammal and Bird Collections at INPA (Manaus, Amazonas state). Determination of taxon specific occurrence in the Tapajos-Xingu interfluve was based on Emmons and Feer (1997), Pimenta and Silva Junior (2005) and Norte Energia (2014).

\subsection{Estimation of food availability}

The relative abundance of food availability to the Harpy Eagle was assessed by combining data sets on species abundance surveys using Rapid Assessment Long-Term Ecological Research Program (RAPELD) method, on modules distributed along the Xingu River channel, and occasional counts of non-volant fauna rescue/flushing on 5352 ha in the Belo Monte Hydroelectric Complex area (Norte Energia, 2014).

Each module was walked between February 2012 and March 2014 for five consecutive days with an average effort of $10 \mathrm{~km} /$ day. Availability data, availability data came from counts conducted in only one (Module 1) (Figure 1) of the eight RAPELD, and compared with the prey species predated at Nest 1 , because we had few replicates of data collection from the other nests. The non-volant fauna rescue and flushing occurred before vegetation removal, in areas designated to be flooded by the reservoir, and were made from Jun 2011 to May 2014 (Norte Energia, 2014).

The RAPELD method spatially standardizes the sampling of biological assemblages over large areas, and minimizes variation in the environmental factors within plots (Magnusson et al., 2005, 2013). Furthermore, the systematic distribution of plots in the landscape allows unbiased estimates of distribution, abundance and biomass of species that can have detectability near $100 \%$ at each site, and standardizes effort for species that are not $100 \%$ detectable, which facilitates comparisons between sites (Magnusson et al., 2005, 2013). 


\subsection{Statistical analyses}

To compare the use of prey by Harpy Eagles feeding young to fledgling at the nest relative to food resource availability, we calculated the prey species frequency based on abundance estimated from systematic surveys from RAPELD module 1 (Figure 1) and the number of individuals rescued/flushed for species recorded previously as prey of Harpy Eagles in the Amazon. Sloth and porcupine frequency could only be estimated from the non-volant fauna rescue/flushing. A chi-square test with Yates correction was used to test the null hypothesis that the proportion of fauna recorded by humans (surveys and rescue) was the same as the proportion of prey species consumed. A Spearman rank-order correlation was performed (Zar, 1999). To predict the total number of species that could be potentially detected in the area, we used the First order Jackknife. Statistical analyses were conducted using the 'vegan' and 'biodiversityR' packages in R 3.2.0 program (R Development Core Team, 2015).

\section{Results}

One hundred sixty-five individuals of 18 species of mammals, birds and reptiles were captured by six Harpy Eagle pairs and brought to the nests between May 2013 and July 2015 (Table 1). The three-toed sloth, Bradypus variegatus (Schinz) (30 records) and the two-toed sloth, Choloepus didactylus (Linnaeus) (27 records) were the most frequent prey (35\%). The brown capuchin monkey Sapajus apella (Linnaeus) (23) represented the majority of the primate prey species, which also included red-handed howler monkey Alouatta belzebul (10), red-bellied titi monkey Callicebus moloch (Hoffmannsegg) (1), squirrel monkey, Saimiri spp. (4), white-nosed bearded saki Chiropotes albinasus (I. Geoffroy \& Deville) (1) and unidentified primates (3). Other prey included the mammals: porcupine Coendou prehensilis (Linnaeus) (26), armadillo Dasypus novemcinctus (Linnaeus) (2), and southern tamandua Tamandua tetradactyla (Linnaeus) (6), South American coati Nasua nasua (Linnaeus) (5), kinkajou

Table 1. Number of individuals of prey species collected at six Harpy Eagle nest sites from May 2013 to July 2015 near the lower and mid-Xingu River, Para, Brazil. Habitat = Arboreal (A), Terrestrial (T).

\begin{tabular}{|c|c|c|c|c|c|c|c|c|}
\hline Prey item & Nest 1 & Nest 2 & Nest 3 & Nest 4 & Nest 5 & Nest 6 & Habitat $^{a}$ & IUCN $^{\prime}$ \\
\hline \multicolumn{9}{|l|}{ MAMMALIA } \\
\hline \multicolumn{9}{|l|}{ Marsupialia } \\
\hline Didelphis marsupialis & 1 & 1 & & 1 & & & $\mathrm{~A}$ & $\mathrm{LC}$ \\
\hline \multicolumn{9}{|l|}{ Xenarthra } \\
\hline Choloepus didactylus & 14 & 1 & 3 & 4 & 3 & 2 & A & $\mathrm{LC}$ \\
\hline Bradypus variegatus & 17 & 4 & 4 & 2 & 2 & 1 & $\mathrm{~A}$ & $\mathrm{LC}$ \\
\hline Tamandua tetradactyla & 3 & 2 & & 1 & & & A & $\mathrm{LC}$ \\
\hline Dasypus novemcinctus & 1 & & 1 & & & & $\mathrm{~T}$ & $\mathrm{LC}$ \\
\hline \multicolumn{9}{|l|}{ Primates } \\
\hline Alouatta belzebul & 3 & 2 & 1 & 3 & 1 & & A & VU \\
\hline Sapajus apella & 15 & 5 & 1 & 1 & 1 & & A & $\mathrm{LC}$ \\
\hline Callicebus moloch & 1 & & & & & & A & $\mathrm{LC}$ \\
\hline Saimiri spp. ${ }^{\mathrm{c}}$ & 1 & 2 & & & 1 & & A & - \\
\hline Chiropotes albinasus & 1 & & & & & & $\mathrm{~A}$ & EN \\
\hline Unidentified primate & 1 & & 1 & & 1 & & A & - \\
\hline \multicolumn{9}{|l|}{ Carnivora } \\
\hline Nasua nasua & 4 & & & 1 & & & $\mathrm{~A}$ & $\mathrm{LC}$ \\
\hline Potos flavus & 1 & & & & & & A & $\mathrm{LC}$ \\
\hline \multicolumn{9}{|l|}{ Artiodactyla } \\
\hline Mazama spp. & 1 & & & 1 & & & A & $\mathrm{LC}$ \\
\hline \multicolumn{9}{|l|}{ Rodentia } \\
\hline Coendou prehensilis & 14 & 3 & 4 & 4 & 1 & & $\mathrm{~A}$ & $\mathrm{LC}$ \\
\hline \multicolumn{9}{|l|}{ AVES } \\
\hline Opisthocomus hoazin & 2 & & & & & & A & $\mathrm{LC}$ \\
\hline Ara ararauna & 1 & & & & & & A & $\mathrm{LC}$ \\
\hline Cracidae & & & & 1 & & & $\mathrm{~A} / \mathrm{T}^{\mathrm{d}}$ & - \\
\hline Unidentified bird & 2 & 2 & & 4 & 2 & 1 & A & - \\
\hline \multicolumn{9}{|l|}{ REPTILIA } \\
\hline Iguana iguana & 6 & & & & & & $\mathrm{~A}$ & $\mathrm{LC}$ \\
\hline
\end{tabular}

${ }^{a}$ Emmons and Feer (1997). ${ }^{b} L C=$ Least Concern, VU = Vulnerable, EN = Endangered (IUCN, 2015). ${ }^{c}$ Two species occur in the study area. ${ }^{\mathrm{D}} \mathrm{Del}$ Hoyo et al. (1994). 
Potos flavus (Schreber) (1), common opossum Didelphis marsupialis (Linnaeus) (3), deer (Mazama spp.) (2) and the birds: hoatzin Opisthocomus hoazin (Statius Muller) (2), blue-and-yellow-macaw Ara ararauna (Linnaeus) (1), Cracidae (1), unidentified birds (11), and one lizard: the common iguana, Iguana iguana (Linnaeus) (6).

Harpy Eagle predation on species was different from the proportion detected by humans (surveys and rescue/flushing) $\left(\chi^{2}=54.23 ; \mathrm{df}=16 ; \mathrm{p}<0.001\right)$. Humans were able to detect $70 \%$ (12) of prey species consumed by Harpy Eagle (17) in the best studied nest (Nest 1). The proportions of prey species taken by Harpy Eagles and detected by humans (surveys and rescue/flushing) (Figure 2) were positively correlated $\left(r_{s}=0.7 ; p<0.001\right)$, where the predation was more on species more abundant. The main prey (sloths and porcupine) were only recorded by rescue/flushing methods. The species-accumulation curve of both methods does not reach an asymptote (Figure 3 ).

\section{Discussion}

The proportion (35\%) of the two species of sloth in the Harpy Eagle diet follows the pattern observed in other studies, which also report a higher frequency of these taxa in the Brazilian Amazon (Galetti and Carvalho Junior, 2000; Aguiar-Silva et al., 2014a), but the percentage of brown capuchin monkeys (23\%) and Brazilian porcupines $(25 \%)$

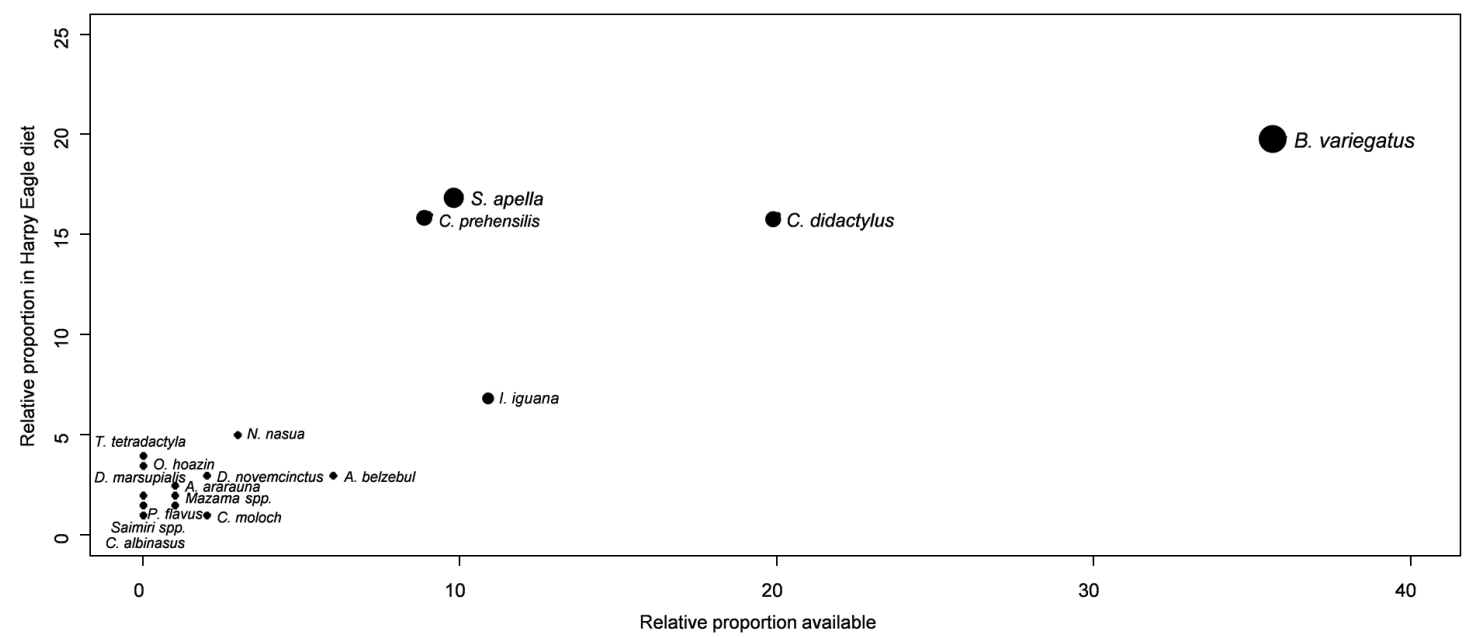

Figure 2. Comparison of the relative proportion available by species estimated as recorded by humans $(\mathrm{n}=3337)$ and consumed $(\mathrm{n}=86)$ by Harpy Eagles at Nest 1 on the mid-Xingu River, eastern Brazilian Amazonia. Species availability data (RAPELD Module 1 and all records during fauna rescue/flushing activities) from 2011-2014 (Norte Energia, 2014).
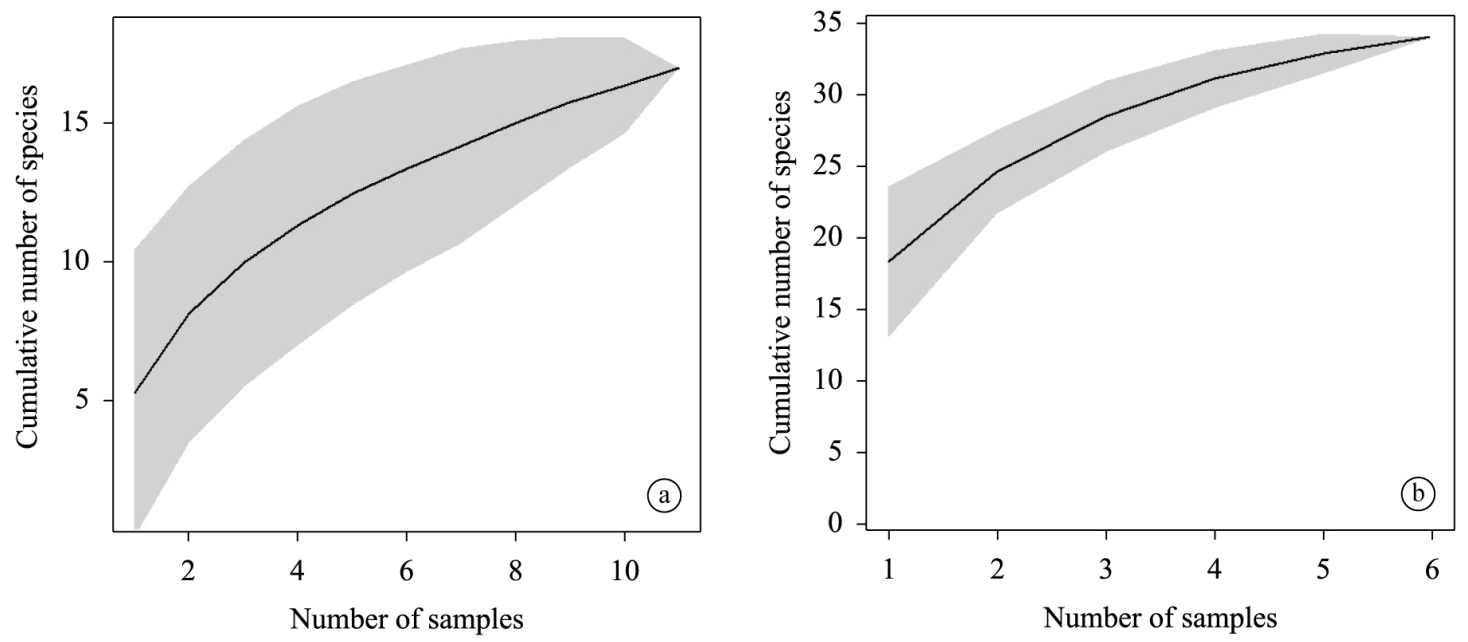

Figure 3. Species accumulation curve of vertebrate species recorded through: a) prey remains species identification on six Harpy Eagle nests; b) diurnal surveys by RAPELD method (Module 1). Mean and standard deviation of species richness, balanced by the cumulative number of samples, estimated using the Jackknife method with replacement. 
was greater than that found in other studies. Other predation records for Harpy Eagle on a primate (Henriques et al., 2008; I. Martins, pers. comm.; D.F. Trombin, pers. comm.), on a porcupine (D.F. Trombin, pers. comm.), and on an iguana (V.P. Palhares, pers. comm.), being eaten at the river edge, were recorded in this study area during vegetation suppression.

It is noteworthy that even though the surroundings of the Harpy Eagle breeding territory have been a target of forest conversion for livestock (Escada et al., 2005; Laurance et al., 2005), there was apparent diversity in prey species consumed (18) and in size classes, since they included small species (opossum, squirrel monkey and hoatzin) and large ones (red-handed howler monkey). Successful Harpy Eagle reproduction with a stable prey base indicates that these breeding territories need to be protected. In the case of the four nest trees which had vegetation suppression immediately surrounding the tree, three of them (Nests 4, 5, 6) with 100\% removed, the pair will probably find a new nest tree around the breeding territory, for the next breeding cycle.

The record of ground-dwelling species, such as armadillos, in the Harpy Eagle diet may indicate that the pair is foraging in open areas. Armadillos in the Harpy Eagle diet have been reported in the mosaic of Protected Areas of Carajás, Para state (Aguiar-Silva et al., 2012), at the Serra da Bodoquena National Park, Mato Grosso do Sul (Milano et al., 2013), in the Brazilian Cerrado, at Barra do Bugres, Mato Grosso state (Rosa, 2012) and in Peru (Piana, 2007). Occurrence of species restricted to or associated with riverine habitats (Remsen and Parker III, 1983), such as the hoatzin and common iguana, indicate that the pair is foraging in riparian areas. Harpy Eagles in this region are foraging in different kinds of habitats, not exclusively in forested areas.

We recorded many records of predation on the brown capuchin monkey, but we recorded only ten cases of predation on the red-handed howler monkey, which is classified as Vulnerable (VU) due to forest conversion and hunting pressure (IUCN, 2015) (Table 1). This may reflect differences in availability because humans also much less frequently detect red-handed howler monkeys than brown capuchin monkeys. Red-handed howler monkey is a large-bodied $(6.5 \mathrm{~kg})$ primate which also has suffered unsustainable hunting pressure, and had their population reduction in several over-hunted areas (Peres, 1997; Peres and Dolman, 2000; Jerozolimski and Peres, 2003), as historically was the process of human colonization in this region of the Amazon (Lopes and Ferrari, 2000). If the difference is not due only to detectability, it may be that the occasional predation by Harpy Eagles is restricting the species in this area.

Humans were able to detect $70 \%$ (12) of prey species consumed by Harpy Eagle (18), however, if we exclude the records from vertebrate rescue/flushing, they recorded $53 \%$ (9) of the total species predated by this predator in the region studied. This suggests that humans were recording the most conspicuous prey by standardized survey method, while can to detect cryptic species only when there is habitat disturbance. Surveys by standardized techniques are deficient in recording nocturnal and cryptic species such as sloths (Galetti and Carvalho Junior, 2000), porcupine and kinkajou. The species accumulation curve of RAPELD method and Harpy Eagle prey consumption does not reached an asymptote (Figure 3), indicating that humans does not recorded the total number of species, and that the Harpy Eagle is not over-using the available resource. However, more analysis need to be conducted in non-altered sites to conclude if this is not a factor of fauna depletion due to hunting or to forest conversion to non-forested land uses.

Analyzing proportion of fauna rescue/flushing and of standardized surveys, there is evidence that Harpy Eagle consumes more prey species which are more abundant. By this, we believe that is possible to use the species assemblage consumed by Harpy Eagle in the nests to allow detection of the assemblage of vertebrate species occurrence around the breeding territories. Changes in Harpy Eagle diet by reduction on diversity and especially in the number of sloths can be used as a proxy to estimate changes on composition vertebrate communities and habitat quality surrounding Harpy Eagle breeding territories.

Analyses including landscape-scale and level of protection around a larger number of breeding territories are recommended to quantify how resilient and persistent Harpy Eagle are in forest fragments (Aguiar-Silva et al., $2014 b$ ), considering changes in the assemblage of prey species composition or local extinction by anthropogenic disturbance (hunting pressure and land-use changes) (Michalski and Peres, 2005). In the Tapajos-Xingu interfluve, which includes the lower Xingu River, nine Harpy Eagle nests have been located, four of which are located inside protected areas (Unidades de Conservação or Indigenous Territories) (Aguiar-Silva et al., 2013). Of the five nests recorded outside protected areas, two no longer exist, because the nest tree was cut down (Aguiar-Silva et al., 2014b), demonstrating the vulnerability of the species outside protected areas.

Composition of diet of the Harpy Eagle may indicate that riverside forest remnants in this area were still an efficient source of food for its reproduction. Continuous monitoring of its diet at these nests can record changes in the assemblage of prey species consumed by this species, subsequent to changes brought by the forest fragmentation, the future full operation of the Belo Monte Hydroelectric Complex and the reduction of the seasonal flood pulse of the Xingu River, which also includes the two areas to be inundated, the Xingu (location of Nest 3 ) and Intermediate (location of Nests 4, 5 and 6) Reservoirs.

We believe that it is important to consider the protection of remnants of forested areas around nests, including the landscape matrix surrounding the breeding territories, and a buffer zone to protect the nests and benefits the fauna and flora communities. A buffer zone radius of $\approx 4.3 \mathrm{~km}$ was estimated in this region based on distance among three neighbor nests (Sanaiotti et al., 2015). These areas 
together will be important for wildlife conservation inside the Belo Monte Hydroelectric Complex, as well as, needs to be included in the Brazilian National Protected Area System (Brasil, 2000), to connect habitats (Brasil, 2012), maintain food resource availability, habitat quality and allow all pairs to successfully reproduce. This action will have high positive conservation impact on the region of the Xingu River, as one form of environmental mitigation in the zones of influence of governmental development projects, including the several dams projected to be constructed along Amazonian rivers (Brasil, 2014c; Fearnside, 2015).

\section{Acknowledgements}

We thank the Coordenação de Aperfeiçoamento de Pessoal de Nível Superior (CAPES), Idea Wild, Birders Exchange, Dean Amadon Grant from the Raptor Research Foundation and The International Osprey Foundation. Travelling assistance came from INPA/Vale S.A./Fundação Amazônica de Defesa da Biosfera partnership. We thank the curators of the biological collections of Birds and Mammals at INPA; Luiza M. P. Henriques, Sidnei Dantas and Tiago O. Laranjeiras, for their photographs and notification of the first nest found at mid-Xingu River; to the teams of Biota and Leme Engenharia (Daiane F. Trombin, Victor Castro, Douglas Fernandes, Lorena Castilho, Valéria P. Palhares, Gustavo Oliveira, Raony de M. Alencar, Denilson Aranha and Sr. Davi, boat manager), Systema Naturae Consultoria Ambiental (Ralder F. Rossi, Carlos E. D. Cintra) and Roberto L. Silva (Norte Energia) for their help with logistical support during mapping and sample collections at the Harpy Eagle nests; Olivier Jaudoin who climbed the nest trees to collect data; and Igor Martins, Daiane F. Trombin, Valéria P. Palhares for photographs about occasional predations. We thank W.E. Magnusson for comments to this manuscript and S.V. Wilson for English revision. This is contribution No. 3 of the Harpy Eagle Conservation Program (PCGR-Brazil).

\section{References}

AGUIAR-SILVA, FH., MARTINS, FD., JAUDOIN, O., CARVALHO, AS., ALVES, AG., PIMENTA, FRP., SANAIOTTI, TM. and LUZ, BB., 2012. Carcaças no dossel: mamíferos predados por Harpia harpyja na floresta nacional de Carajás, Pará. In Anais do $6^{\circ}$ Congresso Brasileiro de Mastozoologia, 2012. Corumbá. São Paulo: Sociedade Paulista de Zoológicos.

AGUIAR-SILVA, FH., SANAIOTTI, TM., JAUDOIN, O., LUZ, BB., MARTINS, FD., SOUSA, GL. and MILANO, MZ., 2013. Harpy Eagle nesting territories in Brazilian Forests, during the past 15 years. In Proceedings of the I Worldwide Raptor Conference, 2013. Bariloche. Argentina: Universidad Nacional del Comahue.

AGUIAR-SILVA, FH., SANAIOTTI, TM., LUZ, BB., JAUDOIN, O. and MATOS, SP., 2014b. Ameaça e conservação das aves de rapina de grande porte na Floresta Nacional do Tapajós e entorno. In Anais do II Seminário de Pesquisa Cientifica da Floresta Nacional do Tapajós, 2014. Santarém. Brasília: ICMBio. p. 22-32.
AGUIAR-SILVA, FH., SANAIOTTI, TM. and LUZ, BB., 2014a. Food habits of the Harpy Eagle, a top predator from the Amazonian rainforest canopy. The Journal of Raptor Research, vol. 48, no. 1, p. 24-35. http://dx.doi.org/10.3356/JRR-13-00017.1.

ALMEIDA, AS., VIEIRA, ICG., BARROS, MNR. and ROCHA, DPN., 2014. Áreas de endemismo Belém e Xingu: configuração e espacialização do uso da terra e da cobertura vegetal. In EMILIO, T. and LUIZÃO, F. (Eds.). Cenários para a Amazônia: clima, biodiversidade e uso da terra. Manaus: Editora INPA. p. 57-66.

ÁLVAREZ-CORDERO, E., 1996. Biology and conservation of the Harpy Eagle in Venezuela and Panamá. Gainesville: University of Florida. 212 p. Doctoral Thesis in Biology.

ANFUSO, J., SUAREZ, MVG. and CHEBEZ, JC., 2008. Nuevo registro de nidificación de la Harpia (Harpia harpyja) en la provincia de misiones y consideraciones sobre su conservación. Nótulas Faunísticas, vol. 21, p. 1-13.

BANHOS, A., HRBEK, T., GRAVENA, W., SANAIOTTI, T. and FARIAS, IP., 2008. Genomic resources for the conservation and management of the Harpy Eagle (Harpia harpyja, Falconiformes, Accipitridae). Genetics and Molecular Biology, vol. 31, no. 1, p. 146-154. http://dx.doi.org/10.1590/S1415-47572008000100025.

Brasil. Instituto Nacional de Pesquisas Espaciais - INPE, 2004. Projeto Prodes: programa de monitoramento da floresta amazonica brasileira por satélite. Brasília: INPE. Available from: $<$ http:// www.obt.inpe.br/prodes/>. Access in: 01 May 2014.

Brasil. Ministério do Meio Ambiente-MMA, 2000. Lei $n^{\circ}$ 9.985, de 18 de julho de 2000 que institui o sistema nacional de unidade de conservação da natureza (SNUC). Decreto $n^{\circ} 4.340$, de 22 de agosto de 2002. 5th ed. Brasília: MMA/SBF. 56 p.

Brasil. Ministério do Meio Ambiente - MMA, Instituto Chico Mendes de Conservação da Biodiversidade - ICMBIO, 2012. Plano de ação nacional para a conservação das espécies endêmicas e ameaçadas de extinção da fauna da região do Baixo e Médio Xingu-PAN Baixo e Médio Xingu. Portaria $N^{o} 16,17$ de fevereiro de 2012. Brasília: Ministério do Meio Ambiente.

Brasil. Ministério do Meio Ambiente - MMA, Instituto Chico Mendes de Conservação da Biodiversidade - ICMBIO, 2014a. Plano de Ação Nacional para Conservação das Aves da Amazônia ameaçadas de extinção, PAN - Aves da Amazônia. Portaria $N^{o} 35$, 27 de Março de 2014. Brasília: Ministério do Meio Ambiente.

Brasil. Ministério do Meio Ambiente - MMA, Instituto Chico Mendes de Conservação da Biodiversidade - ICMBio, 2014b. Lista Nacional das Espécies da Fauna Brasileira Ameaçadas de Extinção. Portaria $N^{o}$ 444, 17 de dezembro de 2014. Brasília: MMA/ICMBio.

Brasil. Ministério de Minas e Energia - MME, Empresa de Pesquisa Energética - EPE, 2014c. Plano decenal de expansão de energia 2023. Brasília: MME/EPE.

DAVIDSON, EA., ARAÚJO, AC., ARTAXO, P., BALCH, JK., BROWN, IF., C BUSTAMANTE, MM., COE, MT., DEFRIES, RS., KELLER, M., LONGO, M., MUNGER, JW., SCHROEDER, W., SOARES FILHO, BS., SOUZA JUNIOR, CM. and WOFSY, SC., 2012. The Amazon basin in transition. Nature, vol. 481, no. 7381 , p. 321-328. http://dx.doi.org/10.1038/nature10717. PMid:22258611.

DELUCA, JJ., 2012. Birds of conservation concern in eastern Acre, Brazil: distributional records, occupancy estimates, humancaused mortality, and opportunities for ecotourism. Tropical Conservation Science, vol. 5, no. 3, p. 301-319. 
Del HOYO, J., ELLIOTT, A. and SARGATAL, J., 1994. Handbook of the birds of the world. New World Vultures to Guineafowl. Barcelona: Lynx Edicions. vol. 2, $638 \mathrm{p}$

EMMONS, LH. and FEER, F., 1997. Neotropical rainforest mammals: a field guide. Chicago: University of Chicago Press.

ESCADA, MIS., VIEIRA, ICG., KAMPEL, SA., ARAÚJO, R., VEIGA, JB., AGUIAR, APD., VEIGA, I., OLIVEIRA, M., PEREIRA, JLG., CARNEIRO FILHO, A., FEARNSIDE, PM., VENTURIERI, A., CARRIELLO, TM., CARNEIRO, TSG., MONTEIRO, AMV. and CÂMARA, G., 2005. Occupation processes in the new Amazonian frontiers: the Xingu/Iriri region. Estudos Avançados, vol. 19, p. 9-23. http://dx.doi.org/10.1590/ S0103-40142005000200002.

FEARNSIDE, PM., 2015. Hidrelétricas na Amazônia: impactos ambientais e sociais na tomada de decisões sobre grandes obras. Manaus: Editora do INPA. vol. 1, 296 p.

FERGUSON-LEES, J. and CHRISTIE, DA., 2001. Raptors of the world. New York: Houghton-Mifflin Company. 992 p.

FOWLER, JM. and COPE, JB., 1964. Notes on the Harpy Eagle in British Guiana. The Auk: Ornithological Advances, vol. 81, no. 3, p. 257-273. http://dx.doi.org/10.2307/4082683.

GALETTI, M. and CARVALHO JUNIOR, O., 2000. Sloths in the diet of a Harpy Eagle nestling in Eastern Amazon. The Wilson Bulletin, vol. 112, no. 4, p. 535-536. http://dx.doi.org/10.1676/00435643(2000)112[0535:SITDOA]2.0.CO;2.

HENRIQUES, LMP., DANTAS, S., SARDELLI, CH., CARNEIRO, LS., BATISTA, RSS., ALMEIDA, CCA., TORRES, MF., SILVA, MC., LARANJEIRAS, TO. and MELO FILHO, JCM., 2008. Diagnóstico avifaunístico da área de influência do AHE Belo Monte como subsídio ao estudo de impacto ambiental (EIA) RIMA). Manaus: INPA. 60 p. Relatório Técnico.

International Union for Conservation of Nature-IUCN, 2015. The IUCN Red List of Threatened Species. Version 2015.1. Available from: <www.iucnredlist.org >. Access in: 20 Jan. 2015.

JEROZOLIMSKI, A. and PERES, CA., 2003. Bringing home the biggest bacon: a cross-site analysis of the structure of hunterkill profiles in Neotropical forests. Biological Conservation, vol. 111, p. 415-425.

JOHNSON, MD., 2007. Measuring habitat quality: a review. The Condor, vol. 109, no. 3, p. 489-504.

LAURANCE, WF., BERGEN, S., COCHRANE, MA., FEARNSIDE, PM., DELAMONICA, P., D'ANGELO, S., BARBER, C. and FERNANDES, T., 2005. The future of the Amazon. In BERMINGHAM, E., DICK, CW. and MORITZ, C. (Eds.). Tropical rainforests: past, present and future. Chicago: University of Chicago Press. p. 583-609.

LOPES, MA. and FERRARI, SF., 2000. Effects of human colonization on the abundance and diversity of mammals in eastern Brazilian Amazonia. Conservation Biology, vol. 14, p. 1658-1665.

MAGNUSSON, WE., BRAGA-NETO, R., PEZZINI, F., BACCARO, FB., BERGALLO, H., PENHA, J., RODRIGUES, D., VERDADE, LM., LIMA, A., ALBERNAZ, A., HERO, JM., LAWSON, B., CASTILHO, C., DRUCKER, D., FRANKLIN, E., MENDONÇA, F., COSTA, F., GALDINO, G., CASTLEY, G., ZUANON, J., VALE, J., SANTOS, JLC., LUIZÃO, R., CINTRA, R., BARBOSA, RI., LISBOA, A., KOBLITZ, RV., CUNHA, CN. and PONTES, ARM., 2013. Biodiversidade e monitoramento ambiental integrado. São Paulo: Áttema. 356 p.

MAGNUSSON, WE., LIMA, AP., LUIZÃO, RC., LUIZÃO, F., COSTA, FRC., CASTILHO, CV. and KINUPP, VF., 2005.
RAPELD: uma modificação do método de Gentry para inventários de biodiversidade em sítios para pesquisa ecológica de longa duração. Biota Neotropica, vol. 5, no. 2, p. 1-6.

MASCARENHAS, BM. and PUORTO, G., 1988. Nonvolant mammals rescued at the Tucuruí Dam in the Brazilian Amazon. Primate Conservation, vol. 9, p. 91-93.

MICHALSKI, F. and PERES, CA., 2005. Anthropogenic determinants of primate and carnivore local extinctions in a fragmented forest landscape of southern Amazonia. Biological Conservation, vol. 124, p. 383-396.

MILANO, MZ., AGUIAR-SILVA, FH., NASCIMENTO, V., ZUGMANN, A., VILLELA, FC., SANAIOTTI, TM., JAUDOIN, O. and SEIXAS, GHF., 2013. Monitoramento de harpia (Harpia harpyja) no Parque Nacional da Serra da Bodoquena, Mato Grosso do Sul. In Anais do V Seminário de Pesquisa do ICMBio, 2013. Brasília. Brasília: ICMBio. p. 79.

MUÑIZ-LÓPEZ, R., CRIOLLO, O. and MENDÚA, A., 2007. Results of five years of the "Harpy Eagle (Harpia harpyja) Research Programme" in the Ecuadorian tropical forest. In BILDSTEIN, KL., BARBER, DR. and ZIMMERMAN, A. (Eds.). Neotropical Raptors. Orwigsburg: Hawk Mountain. p. 23-32. Raptor Conservation Science Series, no. 1.

Norte Energia, 2014. Projeto Básico Ambiental: $6^{\circ}$ Relatório Consolidado de andamento do PBA e do atendimento de condicionantes. Chap. 2. p. 59-88. Available from: <http:// licenciamento.ibama.gov.br/Hidreletricas/Belo\%20Monte/ Relatorios $\% 20$ Semestrais $/ 6 \% \mathrm{C} 2 \% \mathrm{BA} \% 20 \mathrm{RC} \% 20310714 \% 20-\% 20$ PDF/CAP\%C3\%8DTULO\%202/12>. Access in: 06 Nov. 2014.

PACHECO, JF. and OLMOS, F., 2005. Birds of a latitudinal transect in the Tapajós-Xingu interfluvium, eastern Brazilian Amazonia. Revista Brasileira de Ornitologia, vol. 13, p. 29-46.

PERES, CA. and DOLMAN, P., 2000. Density compensation in neotropical primate communities: evidence from 56 hunted and non-hunted Amazonian forests of varying productivity. Oecologia, vol. 122, p. 175-189.

PERES, CA., 1997. Effects of habitat quality and hunting pressure on arboreal folivore densities in Neotropical forests: a case study of howler monkeys (Alouatta spp.). Folia Primatolica, vol. 68, p. 199-222.

PIANA, RP., 2007. Anidamiento y dieta de Harpia harpyja Linnaeus en la comunidad nativa de Infierno, Madre de Dios, Perú. Revista Peruana de Biología, vol. 14, p. 135-138.

PIMENTA, FE. and SILVA JUNIOR, JS., 2005. An update on the distribution of primates of the Tapajós-Xingu interfluvium, Central Amazonia. Neotropical Primates, vol. 13, no. 2, p. 23-28. http://dx.doi.org/10.1896/1413-4705.13.2.23.

R Development Core Team, 2015. R: A language and environment for statistical computing. Vienna: R Foundation for Statistical Computing. Available from: $<$ http://www.R-project.org $>$. Access in: 05 June 2015.

RAVETTA, AL. and FERRARI, SF., 2009. Geographic distribution and population characteristics of the endangered white-fronted spider monkey (Ateles marginatus) on the lower Tapajós River in central Brazilian Amazonia. Primates, vol. 50, no. 3, p. 261-268. http://dx.doi.org/10.1007/s10329-009-0146-1. PMid:19430965.

REMSEN, J. and PARKER III, TA., 1983. Contribution of rivercreated habitats to bird species richness in Amazonia. Biotropica, vol. 15, no. 3, p. 223-231. http://dx.doi.org/10.2307/2387833.

RETTIG, N., 1978. Breeding behavior of the Harpy Eagle (Harpia harpyja). The Auk: Ornithological Advances, vol. 95, p. 257-273. 
ROSA, JM., 2012. Fotos: harpia, a maior águia das Américas. National Geographic Brasil. Available from: <http://viajeaqui. abril.com.br/materias/fotos-harpia-a-maior-aguia-das-americas\#7>. Access in: 01 Feb. 2014.

SANAIOTTI, TM., JUNQUEIRA, TG., PALHARES, V., AGUIAR-SILVA, FH., HENRIQUES, LMP., OLIVEIRA, G., GUIMARÃES, VY., CASTRO, V., MOTA, D., TROMBIN, DF., VILLAR, DNA., LARA, KM., FERNANDES, D., CASTILHO, L., YOSHENO, E., ALENCAR, RM., CESCA, L., DANTAS, SM., LARANJEIRAS, TO., MATHIAS, PC. and MENDONÇA, CV., 2015. Abundance of Harpy and Crested Eagles from a reservoirimpact area in the Low- and Mid-Xingu River. Brazilian Journal of Biology. In press.

SANAIOTTI, TM., RITTL FILHO, C., LUZ, BB. and SOLER, IGP., 2001. Dieta de filhotes de Harpia harpyja na região de Manaus. In STRAUBE, FC. (Ed.). Ornitologia sem fronteiras (incluindo os Resumos do IX Congresso Brasileiro de Ornitologia). Curitiba: PUCPR. p. 345-346.
SOARES FILHO, BS., NEPSTAD, D., CURRAN, CL., CERQUEIRA, GC., GARCIA, RA., RAMOS, CA., VOLL, E., MCDONALD, A., LEFEBVRE, P., SCHLESINGER, P. and MCGRATH, D., 2005. Cenários de desmatamento para a Amazônia. Estudos Avançados, vol. 19, no. 54, p. 137-152. http://dx.doi.org/10.1590/ S0103-40142005000200008.

SOARES, ES., AMARAL, FSR., CARVALHO FILHO, EPM., GRANZINOLLI, MA., ALBUQUERQUE, JLBL., LISBOA, JS., AZEVEDO, MAG., MORAES, W., SANAIOTTI, TM. and GUIMARÃES, IG., 2008. Plano de Ação para Conservação de Aves de Rapina - PANCAR. Brasília: ICMBio. 136 p. ICMBio Série Espécies Ameaçadas, no. 5.

TRINCA, CT., FERRARI, SF. and LEES, AC., 2008. Curiosity killed the bird: arbitrary hunting of Harpy Eagles Harpia harpyja on an agricultural frontier in southern Brazilian Amazonia. Cotinga, vol. 30, p. 12-15.

ZAR, JH., 1999. Biostatistical Analysis. 4th ed. Upper Saddle River: Prentice Hall. 